\title{
Inappropriate prescription of corticosteroid therapy during inflammatory ileo-colitis revealing disseminated tuberculosis with digestive involvement: two case reports
}

\author{
Chantelli Razafindrazoto ${ }^{1}$, Nitah Randramifidy ${ }^{1}$, Jolivet Rakotomalala ${ }^{1}$, Behoavy \\ Ralaizanaka ${ }^{1}$, Mialitiana Rakotomaharo ${ }^{1}$, Hasina Laingonirina ${ }^{1}$, Sonny Maherison ${ }^{1}$, \\ Anjaramalala Rasolonjatovo ${ }^{1}$, Andry Rakotozafindrabe ${ }^{1}$, Tovo Rabenjanahary ${ }^{1}$, Soloniaina \\ Razafimahefa $^{2}$, and Rado Ramanampamonjy ${ }^{1}$ \\ ${ }^{1}$ Université d'Antananarivo \\ ${ }^{2}$ Université de Fianarantsoa
}

March 5, 2021

\begin{abstract}
The similarity between intestinal tuberculosis and Crohn's disease could lead us to erroneously prescribe corticosteroid therapy. Therefore, it is essential to differentiate the two pathologies because of the therapeutic implications of Crohn's disease, which can lead to an explosion of tuberculosis symptoms.
\end{abstract}

Inappropriate prescription of corticosteroid therapy during inflammatory ileo-colitis revealing disseminated tuberculosis with digestive involvement: two case reports

Chantelli Iamblaudiot Razafindrazoto ${ }^{1}$, Nitah Harivony Randriamifidy ${ }^{1}$, Jolivet Auguste Rakotomalala ${ }^{1}$, Behoavy Mahafaly Ralaizanaka ${ }^{3}$, Mialitiana Rakotomaharo ${ }^{1}$, Hasina Domoina Laingonirina ${ }^{1}$, Sonny Maherison $^{1}$, Anjaramalala Sitraka Rasolonjatovo ${ }^{1,2}$, Andry Lalaina Rinà Rakotozafindrabe ${ }^{1,2}$, Tovo Harimanana Rabenjanahary ${ }^{1,2}$, Soloniaina Hélio Razafimahefa ${ }^{3,4}$, Rado Manitrala Ramanampamonjy ${ }^{1,2}$

1. Department of Gastroenterology, University Hospital Joseph Raseta Befelatanana, Antananarivo, Madagascar

2. Faculty of Medicine, University of Antananarivo, Madagascar

3. Department of Hepato-Gastroenterology, University Hospital Andrainjato, Fianarantsoa, Madagascar

4. Faculty of Medicine, University of Fianarantsoa, Madagascar

\section{${ }^{*}$ Correspondence :}

Chantelli I. Razafindrazoto

Unity of Gastroenterology, University Hospital Joseph Raseta Befelatanana, Antananarivo, Madagascar

Full list of author information is available at the end of the article

Email:iamblaudiotchantelli@yahoo.com

\section{Abstract}

The similarity between intestinal tuberculosis and Crohn's disease could lead us to erroneously prescribe corticosteroid therapy. Therefore, it is essential to differentiate the two pathologies because of the therapeutic implications of Crohn's disease, which can lead to an explosion of tuberculosis symptoms. 
KEYWORDS: Gastrointestinal tuberculosis, Crohn's disease, immunosuppressive, Madagascar

\section{Key clinical message}

It is essential to differentiate intestinal tuberculosis from Crohn' disease because of the therapeutic implications of Crohn's disease, which can lead to an explosion of symptoms of tuberculosis.

\section{INTRODUCTION}

Intestinal tuberculosis (ITB) and Crohn's disease (CD) are similar chronic granulomatous diseases making a real diagnostic problem. ${ }^{1,2}$ Gastrointestinal tuberculosis is responsible for significant morbidity and mortality but can be cured with anti-tuberculosis chemotherapy for 6 months. Its frequency is estimated at $3-5 \%^{2,}{ }^{2}$ Crohn's disease is a chronic disease that progresses over time and requires lifelong treatment to maintain remission. It has a high prevalence in industrialized countries but rare in Africa, especially in Sub-Saharan Africa. ${ }^{3,4}$ It is notoriously difficult to differentiate ITB from CD, due to the similarity between the two pathologies from a clinical, radiological, endoscopic and even histopathological point of view. ${ }^{1,3}$ Confusion between these two diseases can lead us to erroneously prescribe corticosteroid therapy. This can worsen the symptoms of tuberculosis (TB) and promote the development of complications. ${ }^{5-7}$ The elimination of ITB before the initiation of immunosuppressive therapy remains fundamental in the event of inflammatory ileocolitis. Our objective is to report two cases of disseminated TB with digestive involvement revealed following corticosteroid therapy in order to alert our colleagues in endemic areas to the dangerousness of initiating corticosteroid therapy without formally ruling out ITB.

\section{CASE REPORT}

\section{CASE 1}

A 31-year-old female accountant was followed up for an outpatient for abdominal pain and deterioration in general condition. The patient had been vaccinated against tuberculosis in childhood according to the expanded immunization program. She had no history of tuberculosis or any notion of tuberculosis contagion in her entourage. Since May 2017, the patient presented with febrile diarrhea, abdominal pain and weight loss. Physical examination showed a defense in the right lumbar and iliac region. The proctological examination was normal. We had not objectified extra-digestive signs (cutaneous, articular, ocular and biliary). The abdominal and pelvic ultrasound on $06 / 08 / 17$ was normal. The ileo-colonoscopy of 06/12/17 showed the presence of deepening, circumferential ulcerations of the right colon and of the low caecal fundus with modification of the ileocaecal valves. The terminal ileum was normal. The histology of the colonic biopsies of 06/23/17 revealed focal ulcerations with a discreet architectural modification, a small focus of basal plasmacytosis, without inflammatory granuloma, without caseous necrosis and without Ziehl stain microstates. Despite the absence of granuloma, the morphological signs of the biopsies could be in favor of Crohn's disease. The first chest x-ray on 07/05/17 was normal. The first test for acid-fast bacilli (AFB) in sputum was negative on $07 / 10 / 17$. All the symptoms suggested severe ileocecal Crohn's disease. Corticosteroid therapy (Solupred?) at a dose of $1 \mathrm{mg} / \mathrm{kg} /$ day was started on $07 / 17 / 17$. The patient was hospitalized on 08/11/17 (1 month from Solupred?) for respiratory distress and increased digestive symptoms. The corticosteroid therapy was immediately stopped. The general examination reported hemodynamic instability with a hypotension $(70 / 40 \mathrm{~mm} \mathrm{Hg})$, tachycardia $(130 / \mathrm{mm})$, tachypnea $(31 / \mathrm{mm})$, oxygen desaturation at $88 \%$ in ambient air and fever at $39.8 \mathrm{degC}$ signifying severe sepsis. Clinical examination reported bilateral pulmonary crackling rales and diffuse abdominal defense. The management of severe sepsis was immediately initiated with filling with physiological serum combined with a double antibiotic therapy such as 3rd generation cephalosporin (Ceftriaxone) and aminoglycoside (Gentamicin). The second chest x-ray of 08/11/17 revealed diffuse bilateral alveolar opacities (Figure 1). The chest CT scan of 08/11/17 showed diffuse heterogeneous infiltrates (Figure 2-a) with a $50 \mathrm{~mm}$ cavitary lesion of the apex of the right lung (Figure 2-b) suggesting tuberculosis. The abdominal and pelvic CT scan of $08 / 11 / 17$ was normal. Laboratory investigations of 08/11/17 showed a clear inflammatory syndrome with a C-reactive Protein (CRP) at $186 \mathrm{mg} / \mathrm{L}$ (Table 1). The second search for acid-alcohol-resistant bacilli in the sputum on 08/14/17 came back positive on direct examination. Severe sepsis in the context of disseminated tuberculosis with digestive involvement 
has been suggested. Anti-tuberculous therapy according to the national protocol was initiated on 08/14/17. The digestive and respiratory outcomes were satisfactory, with appetite resuming after one week of treatment. Apyrexia was only demonstrated from the 17 th day $(08 / 31 / 17)$ of the anti-tuberculous therapy. The diagnosis of disseminated tuberculosis with digestive involvement was made based on clinical, biological, radiological et endoscopic arguments associated with a satisfactory response to anti-tuberculosis treatment. The reassessment of 10/15/2017 reported an absence of clinico-radiological tuberculosis signs and a return to normal weight. The patient had been declared cured at the end of treatment.

\section{CASE 2}

A 51-year-old woman had since December 2020 intermittent episodes of rectal bleeding alternating with febrile diarrhea with a weight loss of $15 \mathrm{~kg}$ in two months requiring her first hospitalization $(01 / 15 / 20)$. The patient did not report a history of tuberculosis or any notion of tuberculosis contagion in her entourage. Initial clinical examination reported mucocutaneous paleness and diffuse abdominal pain. The patient did not present extra-digestive symptoms. Laboratory investigations on $01 / 15 / 20$ showed a significant inflammatory syndrome with a CRP at $186 \mathrm{mg} / \mathrm{L}$ associated with hyperleukocytosis at $22,800 / \mathrm{mm} 3$ and anemia at 10.7 $\mathrm{g} / \mathrm{dL}$ (Table 1). The upper gastrointestinal endoscopy on 01/16/20 was normal. The abdominal and pelvic CT scan of 01/16/20 revealed a thickening of the left colon. The ileo-colonoscopy of $01 / 23 / 20$ revealed circumferential ulcerations and sometimes deep of the rectum (Figure 3-a). Progression stopped at $20 \mathrm{~cm}$ from the anal margin because of an inflammatory stenosis (Figure 3-b). The histology of the rectal biopsies on $02 / 01 / 20$ showed samples consisting of edematous fibrous tissue, densely infiltrated by lymphocytes and polynuclear neutrophils and surrounded by fibrino-leukocyte coatings, without epithelioid granuloma, without lymphocytic follicular hyperplasia, without plasma cell infiltrate, without caseous necrosis and absence of microstates in Ziehl's stain. Deep ulceration points to Crohn's disease, but remains insufficient to make a diagnosis. The absence of plasma cell infiltrate does not allow referral to ulcerative colitis. A collegial decision opted to immediately start corticosteroid therapy (Prednisolone?) and bi-antibiotic therapy (3rd generation cephalosporin + Imidazole) in the context of severe acute colitis on 02/06/20. The patient had opted for discharge against medical advice on $02 / 10 / 20$. The evolution was marked by an increase in digestive, septic and respiratory manifestations with persistence of a gastrointestinal bleeding type melena with severe anemia poorly tolerated after three weeks of treatment, motivating a readmission with immediate stopping of corticosteroids on 03/04/20. General examination showed sepsis with hypotension $(90 / 50 \mathrm{~mm}$ $\mathrm{Hg}$ ), tachycardia (110/min), tachypnea $(29 / \mathrm{min})$, oxygen desaturation at $91 \%$ and fever at $38.5 \mathrm{degC}$. Physical examination reported bilateral alveolar condensation syndrome and diffuse abdominal defense. Laboratory investigations on $03 / 05 / 20$ reported severe anemia at $6.6 \mathrm{~g} / \mathrm{dL}$ hemoglobin and an increased in inflammatory syndrome with CRP at $265 \mathrm{mg} / \mathrm{L}$ and hyperleukocytosis at $24400 / \mathrm{mm}^{3}$ (Table 1 ). The chest x-ray showed bilateral and diffuse interstitial miliary images with some left upper lobe infiltrates suggestive of tuberculosis (Figure 4). The test for acid-fast bacilli was negative on direct examination. A second research was positive on GeneXpert(r). The diagnosis of disseminated tuberculosis with digestive involvement has been suggested. Anti-tuberculous therapy according to the national protocol was initiated immediately on $03 / 09 / 20$. The recto-sigmoidoscopy of $04 / 06 / 20$ showed a clear improvement of the initial lesions with persistence of small ulcerations. The reassessment on $05 / 14 / 20$ was satisfactory with disappearance of digestive, respiratory and infectious manifestations with a return to his normal weight. The patient had been declared cured at the end of treatment. The diagnosis of disseminated tuberculosis with digestive involvement was made based on clinical, biological, radiological et endoscopic arguments associated with a satisfactory response to anti-tuberculosis treatment.

\section{DISCUSSION}

We report two observations of disseminated TB with digestive damage revealed following an inappropriate prescription of corticosteroid therapy in the context of inflammatory ileo-colitis. In Madagascar, it is still very difficult to differentiate intestinal tuberculosis from Crohn's disease due to lack of technical facilities and insufficient resources of patients. We retain that intestinal tuberculosis should be systematically mentioned first in endemic countries in the event of inflammatory ileo-colitis. Prescribing immunosuppressants is 
dangerous in this situation, and should only be prescribed after formal elimination of tuberculosis.

ITB is an extra-pulmonary form of tuberculosis, secondary to hematogenous dissemination, or by local extension following peritoneal involvement or endogenously from swallowed bacilliferous sputum in patients with active pulmonary forms. ${ }^{1,8,9}$ Its frequency is estimated at 3 to 5\%.1, 2 Abdominal tuberculosis mainly affects young adults with a peak frequency between 21 and 45 years. The predominance of women has been observed in countries endemic to TB. Tuberculous involvement mainly concerns the ileum, the ileocecal junction and then the colon. ${ }^{1,8-10} \mathrm{CD}$ remains a very rare disease in Africa, especially in sub-Saharan Africa. ${ }^{3,4}$ In order of frequency, ITB should be mentioned before CD in an endemic TB zone in the event of inflammatory ileo-colitis. ${ }^{3}$

Confusion between ITB and CD poses a real diagnostic problem and a very high diagnostic error rate ranging from 50 to $70 \%$, causing inadequate prescription of corticosteroid therapy. This similarity concerns all aspects of these diseases, clinico-radiological, endoscopic and even histopathological. ${ }^{1,2,3}$ Clinical, radiological and endoscopic criteria have been established by certain authors but they are disappointing. ${ }^{1,3}$ The presence of ascites remains more frequent in the course of TB and has been judged as a more specific clinical criterion in favor of the latter. ${ }^{11}$

Endoscopic differentiation in colonoscopy between ITB and CD is difficult since both diseases can present with mucosal ulcers, apthous ulcers and pseudo-polyps. ${ }^{12,}{ }^{13}$ In the literature, caseous necrosis and the presence of acid-alcohol-resistant bacilli to Ziehl and Nielsen staining allow a definite diagnosis of TB to be established, but are seen in $22 \%$ and $26-36 \%$ respectively. ${ }^{1,8,14,15}$ Therefore, currently available diagnostic confirmation methods have limitations. In our observations, the absence of ascites, gigantocellular granuloma, caseous necrosis during biopsy with absence of acid-fast bacilli at the start misled us and prompted us to erroneously prescribe corticosteroid therapy. This inadequate prescription of corticosteroid therapy led to an explosion of TB symptoms. Demory et al had reported a deceptive case of ITB mimicking CD, leading to inappropriate prescription of corticosteroid therapy, favoring tuberculous explosion with tight stenosis of terminal ileum. ${ }^{7}$ Gargouri etal reported a similar situation where corticosteroid therapy exacerbated TB disease. ${ }^{6}$ In our observations, corticosteroid therapy led to an explosion and dissemination of TB and allowed us to correct our initial diagnosis. Therefore, it is imperative to differentiate these two diseases since the immunosuppressants often used in CD, can lead to an explosion of TB symptoms or even complications which can be fatal. ${ }^{1,5,6,7}$ Tuberculous ileo-colitis should be ruled out before initiating corticosteroid therapy to avoid possible tuberculous complications. ${ }^{1,6,7}$ In our observations, corticosteroid therapy aroused initially inactive pulmonary TB, with secondary appearance of a typical pulmonary radiological image and a positive bascilloscopy. In the literature, this pulmonary involvement can be seen in $9.87 \%$ to $30 \%$ of cases of ITB. ${ }^{8-10}$ The response to TB treatment confirms diagnosis if in doubt. ${ }^{6-8}$ Some authors have even proposed a therapeutic algorithm for inflammatory ileo-colitis, to make our daily exercise more practical (Figure 5). ${ }^{3}$

The management of ITB must be medical and conservative as far as possible, because of the clinical decline of patients (anemia, malnutrition and immunosuppression). ${ }^{16}$ The TB treatment recommended by the majority of guideline in adults is a daily treatment in two phases spread over two months of initial quadruple therapy (Isoniazid, Rifampicin, Pyrazinamide and Ethambutol) followed by 4 to 7 months of dual therapy (Isoniazid and Rifampicin) in maintenance. ${ }^{1,16-18}$ The effectiveness of medical treatment is judged on the disappearance of fever, ascites and weight gain in 4-6 weeks. ${ }^{16-19}$ Surgery should be reserved for complicated forms. ${ }^{20}$ Our two patients had received a 6 -months medical treatment with satisfactory outcome and were declared cured at the end of treatment.

\section{CONCLUSION}

ITB and CD are similar chronic granulomatous diseases, posing a real diagnostic problem. We reported two observations showing an initial diagnostic error in the context of inflammatory ileo-colitis which was almost fatal for our patients due to the spread of tuberculosis after corticosteroid therapy. It is essential to differentiate the 2 pathologies because of the therapeutic implications of $\mathrm{CD}$, which can lead to an explosion of tuberculosis symptoms. To date, the diagnosis of ITB remains difficult to achieve in Madagascar. Treatment 
of ITB should be medical and conservative. Only the complicated forms should resort to surgery.

\section{ABBREVIATIONS}

TB: Tuberculosis, ITB: Intestinal tuberculosis, CD: Crohn's Disease, ALT: Alanine amino-transferase, AST: Aspartate amino-transferase, CRP: C-reactive Protein, HIV: Human Immunodeficiency virus, MCV: Mean corpuscular volume, PL: Prothrombin Level, CTA: Cephalin time activated, PNN: Polynuclear neutrophil.

\section{ACKNOWLEDGMENTS}

We gratefully acknowledge the work of members of our hospital. There was no financial support for this study. Written informed consent was obtained from the participant.

\section{CONFLICT OF INTERESTS}

None declared.

\section{AUTHORS CONTRIBUTIONS}

CIR : were the main contributors to drafting the manuscript. NHR and JAR: contributed to literature search, data collection and figure preparation. BMR, MR, HDL, SM, ASR, ALRR, THR: contributed in management of patients in hospital and performed the final manuscript. SHR: contributed to performed the final manuscript. RMR : contributed to study design, performed the final manuscript. All authors have read and approved the manuscript.

\section{ETHICAL STATEMENT}

The project was approved by the hierarchical heads of University Hospital Joseph Raseta Befelatanana, Antananarivo. Written consent was obtained from the patient for publication of this case report and the accompanying images.

\section{AVAILABILITY OF DATA AND MATERIALS}

Data available on request from the corresponding author.

\section{REFERENCES}

1. Ben Chaabane N, Ben Mansour W, Hellara O, et al. Gastro-intestinal tuberculosis. Hepato Gastro. 2012; $19: 28-35$.

2. Donoghue HD, Holton J. Intestinal tuberculosis. Curr Opin Infect Dis. 2009 ; 22 : 490-6.

3. Epstein D, Watermeyer G, Kirsch R. Review article: the diagnosis and management of Crohn's disease in populations with high-risk rates for tuberculosis. Aliment Pharmacol Ther. 2007; 25: 1373-88.

4. Eric. L, Guillaume S, Claire G. Epidemiologie et histoire naturelle des MICI. Gastroenterol Clin Biol. $2003 ; 27(3): 76-80$.

5. Kentley J, Ooi JL, Potter J, et al. Intestinal tuberculosis: a diagnostic challenge. Trop Med Int Health . 2017; 22(8): 994-99.

6. Gargouri L, Boudabous M, Safi F, et al. tuberculose intestinale ou maladie de Crohn : un defi diagnostique. Archives de Pediatrie.2014 ; 2 : 1123-26.

7. Demory D, Forel J-L, Michel F, et al. Maladie de Crohn ou tuberculose digestive: complications liees a une erreur diagnostique. Presse Med . 2006 ; 35 : 51-4.

8. Marshall JB. Tuberculosis of the gastrointestinal tract and peritoneum. Am J Gastroenterol. 1993;88:989-98.

9. Cagatay A, Caliskan Y, Aksoz S, et al. Extrapulmonary tuberculosis in immunocompetent adults. Scand J Infect Dis. 2004;36: 799-806.

10. Saaiq M, Shah SA, Zubair M. Abdominal tuberculosis: epidemiologic profile and management experience of 233 cases. J Pak Med Assoc. 2012;62:704-7.

11. Uzunkoy A, Harma M, Harma M. Diagnosis of abdominal tuberculosis: experience from 11 cases and review of the literature. World J Gastroenterol. 2004;15(10):3647-9. 
12. Yu H, Liu Y, Wang Y, et al. Clinical, endoscopic and histological differentiations between Crohn's disease and intestinal tuberculosis.Digestion. 2012;85:202-9.

13. Lee YJ, Yang SK, Byeon JS, et al. Analysis of colonoscopic findings in the differential diagnosis between intestinal tuberculosis and Crohn's disease. Endoscopy. 2006;38:592-7.

14. Almadi MA, Ghosh S, Aljebreen AM. Differentiating intestinal tuberculosis from Crohn's disease: a diagnostic challenge. Am J Gastroenterol. 2009 ; 104: 1003-12.

15. Leung VK, Law ST, Lam CW, et al. Intestinal tuberculosis in a regional hospital in Hong Kong: a 10-year experience. Hong Kong Med J.2006;12:264-71.

16. Balasubramanian R, Nagarajan M, Balambal R, et al. Randomised controlled clinical trial of short course chemotherapy in abdominal tuberculosis: a five-year report. Int J Tuberc Lung Dis. 1997; 1: 44-51.

17. Tony J, Sunilkumar K, Thomas V. Randomized controlled trial of DOTS versus conventional regime for treatment of ileocecal and colonic tuberculosis. Indian J Gastroenterol. 2008;27: 19-21.

18. Sarkar DN, Amin R, Mohammad H, et al. Treatment outcome of national guideline based antitubercular chemotherapy in tubercular ascites patients. Mymensingh Med J. 2013;22:358-64.

19. Pablos-Mendez G. Global surveillance for antituberculosis-drug resistance, 1994-1997. N Engl J Med. 1998 ; 338: 1641-9.

20. Hassan I, Brilakis ES, Thompson RL, et al. Surgical management of abdominal tuberculosis. $J$ Gastrointest Surg. $2002 ; 6$ : 862-7.

TABLE 1: Laboratory tests of our patients upon admission and readmission

\begin{tabular}{|c|c|c|c|c|}
\hline Biology tests & Cut-off values & Case 1 & Case 2 & Case 2 \\
\hline & & $(11.08 .17)$ & $\begin{array}{l}\text { First admission } \\
(15 / 01 / 2020)\end{array}$ & $\begin{array}{l}\text { Readmission } \\
(05.03 .20)\end{array}$ \\
\hline $\begin{array}{l}\text { Hemoglobin } \\
(\mathrm{g} / \mathrm{L})\end{array}$ & $110-160$ & 116 & 10,7 & 66 \\
\hline $\operatorname{MCV}(\mathrm{fL})$ & $80-95$ & 80,70 & 87,7 & 86 \\
\hline $\begin{array}{l}\text { Leukocytes } \\
(\mathrm{G} / \mathrm{L})\end{array}$ & $3,8-11$ & 10,22 & 22,80 & 24,40 \\
\hline PNN (G/L) & $2,0-7,5$ & 7,154 & 19,836 & 20,984 \\
\hline $\begin{array}{l}\text { Lymphocytes } \\
\text { (G/L) }\end{array}$ & $1-4,8$ & 1,298 & 2,280 & 2,440 \\
\hline Platelets (G/L) & $150-450$ & 441 & 524 & 289 \\
\hline PL / CTA ratio & $\begin{array}{l}75-100 \% / \\
0,80-1,20\end{array}$ & $100 \% / 0,90$ & $95 \% / 0,86$ & $86 \% / 0,79$ \\
\hline 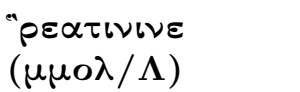 & $44-105$ & 67 & 75 & 54 \\
\hline $\begin{array}{l}\text { Ferritin } \\
(\mathrm{ng} / \mathrm{mL})\end{array}$ & $4,63-204$ & 15 & 120 & 72 \\
\hline $\begin{array}{l}\text { Total } \\
\text { Protidemia } \\
\text { (g/L) }\end{array}$ & $64-83$ & 77 & 54 & 46 \\
\hline $\begin{array}{l}\text { Albuminemia } \\
(\mathrm{g} / \mathrm{L})\end{array}$ & $35-53$ & 40,50 & 31 & 26 \\
\hline $\operatorname{AST}(\mathbf{U} / \mathbf{L})$ & $<35$ & 11 & 10 & 16,3 \\
\hline $\operatorname{ALT}(\mathbf{U} / \mathbf{L})$ & $<45$ & 5 & 16,3 & 10,0 \\
\hline CRP (mg/L) & $<10$ & 186 & 108 & 265 \\
\hline HIV & - & Negative & Negative & - \\
\hline Stool culture & - & Negative & Negative & - \\
\hline $\begin{array}{l}\text { Parasitological } \\
\text { test of stool }\end{array}$ & - & Negative & Negative & - \\
\hline
\end{tabular}




\begin{tabular}{|c|c|c|c|c|}
\hline Biology tests & Cut-off values & Case 1 & Case 2 & Case 2 \\
\hline $\begin{array}{l}\text { Calprotectin } \\
(\mathrm{mg} / \mathrm{kg})\end{array}$ & $<50$ & 493 & - & - \\
\hline $\begin{array}{l}\text { ALT: Alanine } \\
\text { amino- } \\
\text { transferase, AST: }\end{array}$ & $\begin{array}{l}\text { ALT: Alanine } \\
\text { amino- } \\
\text { transferase, AST: }\end{array}$ & $\begin{array}{l}\text { ALT: Alanine } \\
\text { amino- } \\
\text { transferase, AST: }\end{array}$ & $\begin{array}{l}\text { ALT: Alanine } \\
\text { amino- } \\
\text { transferase, AST: }\end{array}$ & $\begin{array}{l}\text { ALT: Alanine } \\
\text { amino- } \\
\text { transferase, AST: }\end{array}$ \\
\hline $\begin{array}{l}\text { Aspartate amino- } \\
\text { transferase, CRP: } \\
\text { C-reactive }\end{array}$ & $\begin{array}{l}\text { Aspartate amino- } \\
\text { transferase, CRP: } \\
\text { C-reactive }\end{array}$ & $\begin{array}{l}\text { Aspartate amino- } \\
\text { transferase, CRP: } \\
\text { C-reactive }\end{array}$ & $\begin{array}{l}\text { Aspartate amino- } \\
\text { transferase, CRP: } \\
\text { C-reactive }\end{array}$ & $\begin{array}{l}\text { Aspartate amino- } \\
\text { transferase, CRP: } \\
\text { C-reactive }\end{array}$ \\
\hline Protein, HIV: & Protein, HIV: & Protein, HIV: & Protein, HIV: & Protein, HIV: \\
\hline Human & Human & Human & Human & Human \\
\hline $\begin{array}{l}\text { Immunodeficiency } \\
\text { virus, MCV: }\end{array}$ & $\begin{array}{l}\text { Immunodeficiency } \\
\text { virus, MCV: }\end{array}$ & $\begin{array}{l}\text { Immunodeficiency } \\
\text { virus, MCV: }\end{array}$ & $\begin{array}{l}\text { Immunodeficiency } \\
\text { virus, MCV: }\end{array}$ & $\begin{array}{l}\text { Immunodeficiency } \\
\text { virus, MCV: }\end{array}$ \\
\hline $\begin{array}{l}\text { Mean corpuscular } \\
\text { volume, PL: }\end{array}$ & $\begin{array}{l}\text { Mean corpuscular } \\
\text { volume, PL: }\end{array}$ & $\begin{array}{l}\text { Mean corpuscular } \\
\text { volume, PL: }\end{array}$ & $\begin{array}{l}\text { Mean corpuscular } \\
\text { volume, } \mathrm{PL} \text { : }\end{array}$ & $\begin{array}{l}\text { Mean corpuscular } \\
\text { volume, PL: }\end{array}$ \\
\hline Prothrombin & Prothrombin & Prothrombin & Prothrombin & Prothrombin \\
\hline Level, CTA: & Level, CTA: & Level, CTA: & Level, CTA: & Level, CTA: \\
\hline $\begin{array}{l}\text { Cephalin time } \\
\text { activated, PNN: } \\
\text { Polynuclear } \\
\text { neutrophil. }\end{array}$ & $\begin{array}{l}\text { Cephalin time } \\
\text { activated, PNN: } \\
\text { Polynuclear } \\
\text { neutrophil. }\end{array}$ & $\begin{array}{l}\text { Cephalin time } \\
\text { activated, PNN: } \\
\text { Polynuclear } \\
\text { neutrophil. }\end{array}$ & $\begin{array}{l}\text { Cephalin time } \\
\text { activated, PNN: } \\
\text { Polynuclear } \\
\text { neutrophil. }\end{array}$ & $\begin{array}{l}\text { Cephalin time } \\
\text { activated, PNN: } \\
\text { Polynuclear } \\
\text { neutrophil. }\end{array}$ \\
\hline
\end{tabular}

\section{FIGURES}

FIGURE 1: Chest x-ray in 31-year-old woman (Case 1) shows diffuse bilateral alveolar opacities.

FIGURE 2 a, b: Chest CT scan in 31-year-old woman (Case 1) shows diffuse heterogeneous infiltrates (a ) with a $50 \mathrm{~mm}$ cavitary lesion of the apex of the right lung (b ).

FIGURE 3 a, b: Coloscopy in 51-year-old woman (Case 2) shows circumferential ulcerations and sometimes deep of the rectum (a) and inflammatory stenosis at $20 \mathrm{~cm}$ from the anal margin (b ).

FIGURE 4: Chest x-ray in 51-year-old woman (Case 2) shows bilateral and diffuse interstitial miliary images with some left upper lobe infiltrates.

FIGURE 5: Treatment algorithm - Intestinal tuberculosis vs Crohn's Disease. Epstein D, Watermeyer G, Kirsch R. Review article: the diagnosis and management of Crohn's disease in populations with high-risk rates for tuberculosis. Aliment Pharmacol Ther. 2007; 25: 1373-88.

\section{Hosted file}

FIGURE Case 1.pptx available at https://authorea.com/users/344473/articles/512186inappropriate-prescription-of-corticosteroid-therapy-during-inflammatory-ileo-colitisrevealing-disseminated-tuberculosis-with-digestive-involvement-two-case-reports

\section{Hosted file}

FIGURE Case 2.pptx available at https://authorea.com/users/344473/articles/512186inappropriate-prescription-of-corticosteroid-therapy-during-inflammatory-ileo-colitisrevealing-disseminated-tuberculosis-with-digestive-involvement-two-case-reports

\section{Hosted file}

FIGURE 5.pptx available at https://authorea.com/users/344473/articles/512186-inappropriateprescription-of-corticosteroid-therapy-during-inflammatory-ileo-colitis-revealingdisseminated-tuberculosis-with-digestive-involvement-two-case-reports 